\title{
REPRESENTASI SEKS BEBAS PADA LIRIK LAGU DANGDUT (ANALISIS SEMIOTIKA SAUSSURE PADA LIRIK LAGU “CINTA SATU MALAM”)
}

\author{
Septia Winduwati ${ }^{1}$ \\ ${ }^{1}$ Fakultas Ilmu Komunikasi Universitas Tarumanagara \\ Email : septiaw@ fikom.untar.ac.id
}

\begin{abstract}
ABSTRAK
Penelitian ini membahas bagaimana lagu dangdut "Cinta Satu Malam” yang dipopulerkan Melinda tahun 2009 merepresentasikan seks bebas. Dengan menggunakan konsep musik sebagai karya atau produk komunikasi massa dan representasi dalam teori kajian budaya, penelitian ini berusaha mencari tahu bagaimana seks bebas direpresentasikan dalam sebuah lagu dangdut. Penelitian ini menggunakan pendekatan kualitatif deskriptif, serta teknik analisis teks wacana semiotika Saussure dalam membedah dan mengkaji lirik lagu tersebut. Dalam penelitian ini ditemukan hasil bahwa bahasa yang digunakan dalam lirik lagu "Cinta Satu Malam” secara explisit merepresentasikan fenomena seks bebas sebagai salah satu realitas sosial serta menunjukkan terdapat suatu pergeseran nilai bahasa khususnya pada pemilihan kata pada lagu dangdut.
\end{abstract}

Kata kunci: Representasi, musik dangdut, seks bebas, semiotika, cinta satu malam Melinda

\section{Pendahuluan}

\section{Latar Belakang}

Musik merupakan salah satu bentuk hiburan yang ditampilkan oleh media massa yang digunakan untuk menyampaikan berbagai pesan yang diangkat dari masalah sosial dalam kehidupan seharihari melalui lirik yang digunakan (Sobur, 2003). Musik juga dapat menjadi media untuk mengungkapkan berbagai realitas kehidupan manusia pada umumnya, dan kehidupan sosial pada khususnya. Pesan atau makna dalam musik pada prinsipnya bervariasi tergantung pada realitas sosial dan ideologi masing-masing kelompok, tak terkecuali musik dangdut.

Pernyataan tersebut juga didukung tulisan Luaylik dan Khusyairi (2012) dalam artikel "Perkembangan Musik Dangdut Indonesia 1960-an-1990an" bahwa musik dangdut tidak hanya berlaku sebagai media hiburan semata, tapi juga sebagai media komunikasi sosial. Djohan (dalam Kurniawan, 2009) menjelaskan bahwa musik merupakan perilaku sosial yang kompleks dan universal yang di dalamnya memuat sebuah ungkapan pikiran manusia, gagasan dan ide-ide dari otak yang mengandung sebuah sinyal pesan yang signifikan. Dengan kata lain, musik bisa mewakili segala ungkapan yang ada dalam pikiran manusia, menyangkut pengalaman maupun harapan.

Lirik lagu pada musik merupakan ekspresi dari pencipta lagu yang menggunakan permainan kata-kata dan bahasa untuk menciptakan daya tarik. Frederick \& Kesumah (dalam Luaylik dan Khusyairi, 2012) menitikberatkan bagaimana dangdut memiliki keterikatan dengan budaya populer yang berkembang di masyarakat dan tidaklah jarang perkembangan musik dangdut sangat lekat pula dengan selera masyarakat. Atas hal tersebut, syair atau lirik dalam lagu dangdut yang diangkat dari realitas atau berdasarkan lingkungan sekitar, wajar jika lirik lagu lebih banyak mengungkapkan realitas hidup masyarakat (khususnya kelas masyarakat bawah) dan 
digunakan untuk melampiaskan berbagai perasaannya yang tertekan, misalnya tema percintaan; yang menceritakan kasus perselingkuhan, pacaran, bahkan pola hidup bebas seperti seks bebas.

Dangdut juga merupakan salah satu jenis musik yang banyak berkembang dan memiliki pasar yang luas. Sebagai salah satu genre musik yang berkembang di Indonesia, dangdut merupakan pencampuran unsur-unsur musik Melayu, Arab dan India. Kata dangdut sendiri berasal dari bahasa Jawa yang diambil dari bunyi tabla (gendang yang digunakan dalam pertunjukan musik dangdut ) "dang" dan "dut". Hal tersebut dibuktikan secara tekstual pada penggalan lirik lagu "Terajana" oleh Rhoma Irama pada tahun 1973 yang berbunyi; "Sulingnya suling bambu, gendangnya kulit lembu, dangdut suara gendang rasa ingin berdendang" (Suryadi, 2013)

Musik ini didominasi irama yang mengajak bergoyang dan pesan yang merakyat. Dangdut juga dikatakan bersifat massa karena disukai banyak orang, diciptakan untuk menarik perhatian banyak orang. Jika merusuk referensi budaya populer, dangdut juga merupakan salah satu produk budaya yang dibuat oleh sekelompok orang untuk mereka sendiri (Storey, 2006). Salah satu lagu dangdut yang berusaha mengungkapkan realitas masyarakat adalah lagu "Cinta Satu Malam" yang dibawakan Melinda. Lagu "Cinta Satu Malam" merupakan lagu yang mengekspresikan pengungkapan rasa cinta sepasang manusia dan sedikit banyak juga menggambarkan pergaulan masyarakat pada saat lagu tersebut populer. Bahasa yang bersifat eksplisit lebih banyak ditampilkan dalam lagu ini, sehingga makna yang terkandung di dalamnya lebih terbuka. Hal ini didukung oleh perkembangan karakter masyarakat yang sekarang juga telah lebih terbuka akan hal-hal yang dulunya dianggap tabu. Permasalahan yang diangkat dalam penelitian ini pada dasarnya berusaha menggambarkan bagaimana representasi seks bebas sebagai salah satu realitas sosial di tengah masyarakat.

Representasi merupakan hal yang tak bisa lepas dari penyampaian pesan di media. Representasi dalam media didefinisikan sebagai penggunaan tanda-tanda (gambar, suara dan sebagainya) untuk menampilkan ulang sesuatu yang dicerap, diindra, dibayangkan atau dirasakan dalam bentuk fisik (Danesi, 2010: 3). Sedangkan Hall (dalam Wiradinata, 2012) mengasumsikan dua proses representasi yakni representasi mental (konsep tentang sesuatu yang ada di kepala kita masing-masing dan masih berbentuk abstrak) dan bahasa yang berperan penting dalam proses konstruksi makna. Terkait penelitian ini, musik dangdut berlaku sebagai media yang menjadi wadah dalam merepresentasikan sesuatu kepada khalayak dan hal tersebut dianggap sebagai realitas yang ada di dalam kehidupan sosial masyarakat.

\section{Rumusan Masalah}

Pertanyaan yang mendasar dalam penelitian ini adalah bagaimana lagu "Cinta Satu Malam" merepresentasikan seks bebas yang dituangkan dalam lagu tersebut?

\section{METODE PENELITIAN}

Penelitian ini menggunakan paradigma konstruktivis sesuai dengan rujukan referensi Nazir (2003) secara ontologi, penelitian ini bertujuan menemukan realitas yang ada dalam lirik lagu "Cinta Satu Malam" yang menggambarkan (1) suatu konstruksi sosial yang terjadi masyarakat yang bersifat relatif sehingga perlu untuk diteliti; (2) Secara epistemologis, penelitian ini berusaha membedah realitas yang ada dengan menganalisa isi teks yang terkandung dalam lirik lagu "Cinta Satu Malam"; (3) Secara aksiologis, penelitian ini bertujuan untuk memfasilitasi khalayak dalam melihat rekonstruksi sosial yang terjadi di masyarakat dengan menganalisa lirik lagu "Cinta Satu Malam"; (4) Secara metodologis, penelitian ini bertujuan merefleksi realitas 
sosial yang terbangun dalam masyarakat dengan menekankan empati terhadap fenomena yang ada melalui analisa isi teks lirik lagu "Cinta Satu Malam".

Pendekatan yang digunakan pada penelitian ini adalah pendekatan kualitatif. Penelitian ini bersifat deskriptif karena hanya memaparkan analisa teks yang menggambarkan realitas sosial dalam masyarakat yang tertuang secara eksplisit dalam lirik lagu "Cinta Satu Malam". Lagu "Cinta Satu" Malam dipilih karena semenjak dirilis, lagu ini cukup digemari oleh masyarakat. Lirik lagu tersebut menunjukkan realitas fenomena sosial secara eksplisit. Fenomena sosial yang diangkat adalah seks bebas yang saat ini menjadi hal lumrah bagi sebagian besar kalangan untuk dibicarakan. Dengan demikian, unit yang dianalisis pada penelitian ini adalah lirik lagu "Cinta Satu Malam”.

Pemilihan lirik lagu sebagai unit analisis adalah karena penggunaan teori semiotika sebagai dasar pemikiran dari penelitian ini. Pembahasan lirik lagu ini akan menggunakan teori Semiotika Saussure yang mengacu pada signifier (penanda, bentuk) dan signified (petanda, makna), dengan hubungan antara penanda dan petanda. Secara sederhana, signifier adalah bunyi yang bermakna atau coretan yang bermakna (aspek material), yakni apa yang dikatakan dan apa yang ditulis atau dibaca. Sementara itu signified adalah gambaran mental, yakni pikiran atau konsep aspek mental dari bahasa (Sobur, 2004). Terkait dengan tanda dan kata, setiap kata dapat menggantikan nama benda (atau konsep) apabila telah diterima oeh konsensus atau konvensi masyarakat, bahkan pada kenyataannya setiap ekspresi yang digunakan dalam masyarakat diperoleh berdasarkan perilaku kolektif atau kesepakatan (Fanani, 2013).

\title{
3. HASIL DAN PEMBAHASAN
}

Lagu "Cinta Satu Malam" merupakan salah satu lagu dangdut berirama house music. Lagu ini lebih bercerita tentang pengungkapan perasaan seseorang yang menjalin cinta dan mengalami "cinta" semalam. Lirik lagu "Cinta Satu Malam" ini adalah :

\author{
Walau cinta kita sementara \\ Aku merasa bahagia \\ Kalau kau kecup mesra di keningku \\ Ku rasa bagai di Surga \\ Sentuhanmu membuatku terlena \\ Aku telah terbuai mesra \\ Yang ku rasa hangat indahnya cinta \\ Hasratku kian membara \\ Reff: \\ Cinta satu malam, oh indahnya \\ Cinta satu malam buatku melayang \\ Walau satu malam akan selalu ku kenang \\ Dalam hidupku \\ Cinta satu malam, oh indahnya \\ Cinta satu malam buatku melayang \\ Walau satu malam akan selalu ku kenang \\ Selama-lamanya
}

Lagu tersebut dibawakan oleh Melinda yang lahir pada 29 Mei 1982 di Jakarta. Melinda yang biasa dipanggil Meli mengeluarkan single teranyarnya, "Cinta Satu Malam", pada awal November 2009 di album ke enam. Lagu dangdut tersebut lebih dipilih dengan mengusung genre 
dangdut house karena lebih identik dengan anak muda. Melalui lagu "Cinta Satu malam", Melinda menuai sukses. Analisis lagu Cinta Satu Malam adalah sebagai berikut :

Tabel 1. Analisis Kualitatif Semiotika Lagu 'Cinta Satu Malam’ Melinda

\begin{tabular}{|c|c|c|c|c|c|}
\hline $\begin{array}{l}\text { Lirik } \\
\text { Lagu }\end{array}$ & $\begin{array}{c}\text { Analisis di } \\
\text { level kata }\end{array}$ & Penanda & Petanda & Denotasi & Konotasi \\
\hline \multirow[t]{4}{*}{$\begin{array}{l}\text { Walau cinta } \\
\text { kita } \\
\text { sementara }\end{array}$} & Cinta kita & Cinta kita & $\begin{array}{l}\text { Perasaan sayang, } \\
\text { suka, saling } \\
\text { tertarik antara } \\
\text { penyanyi dengan } \\
\text { lawan bicara. }\end{array}$ & $\begin{array}{l}\text { Cinta : suka sekali; sayang } \\
\text { benar; kasih sekali; terpikat } \\
\text { (antara laki-laki dan } \\
\text { perempuan). } \\
\text { Kita:pronomina persona } \\
\text { pertama jamak, yang } \\
\text { berbicara bersama dengan } \\
\text { orang lain termasuk yang } \\
\text { diajak bicara. }\end{array}$ & $\begin{array}{l}\text { Ikatan batin antara } \\
\text { dua insan yang } \\
\text { menunjukkan } \\
\text { adanya hubungan } \\
\text { istimewa. }\end{array}$ \\
\hline & $\begin{array}{l}\text { Walau } \\
\text { sementara }\end{array}$ & $\begin{array}{l}\text { Walau } \\
\text { sementara }\end{array}$ & $\begin{array}{l}\text { Jangka waktu } \\
\text { yang relatif } \\
\text { singkat, } \\
\text { temporer (tidak } \\
\text { selamanya). }\end{array}$ & $\begin{array}{l}\text { Walau: dan jika; kendati, } \\
\text { meski } \\
\text { Sementara : selagi; berapa } \\
\text { lamanya; tidak selamanya, } \\
\text { tidak untuk selama-lamanya. }\end{array}$ & $\begin{array}{l}\text { Suatu kejadian yang } \\
\text { berjalan sepintas } \\
\text { lalu. }\end{array}$ \\
\hline & $\begin{array}{l}\text { Analisis di } \\
\text { level } \\
\text { Kalimat }\end{array}$ & Penanda & Petanda & Denotasi & Konotasi \\
\hline & $\begin{array}{l}\text { Walau } \\
\text { cinta kita } \\
\text { sementara }\end{array}$ & idem & idem & Idem & $\begin{array}{l}\text { Meski hubungan } \\
\text { asmara si penyanyi } \\
\text { dan pasangannya } \\
\text { hanya terjadi dalam } \\
\text { waktu singkat. }\end{array}$ \\
\hline
\end{tabular}

Tabel 2. Analisis Kualitatif Semiotika Lagu 'Cinta Satu Malam’ Melinda

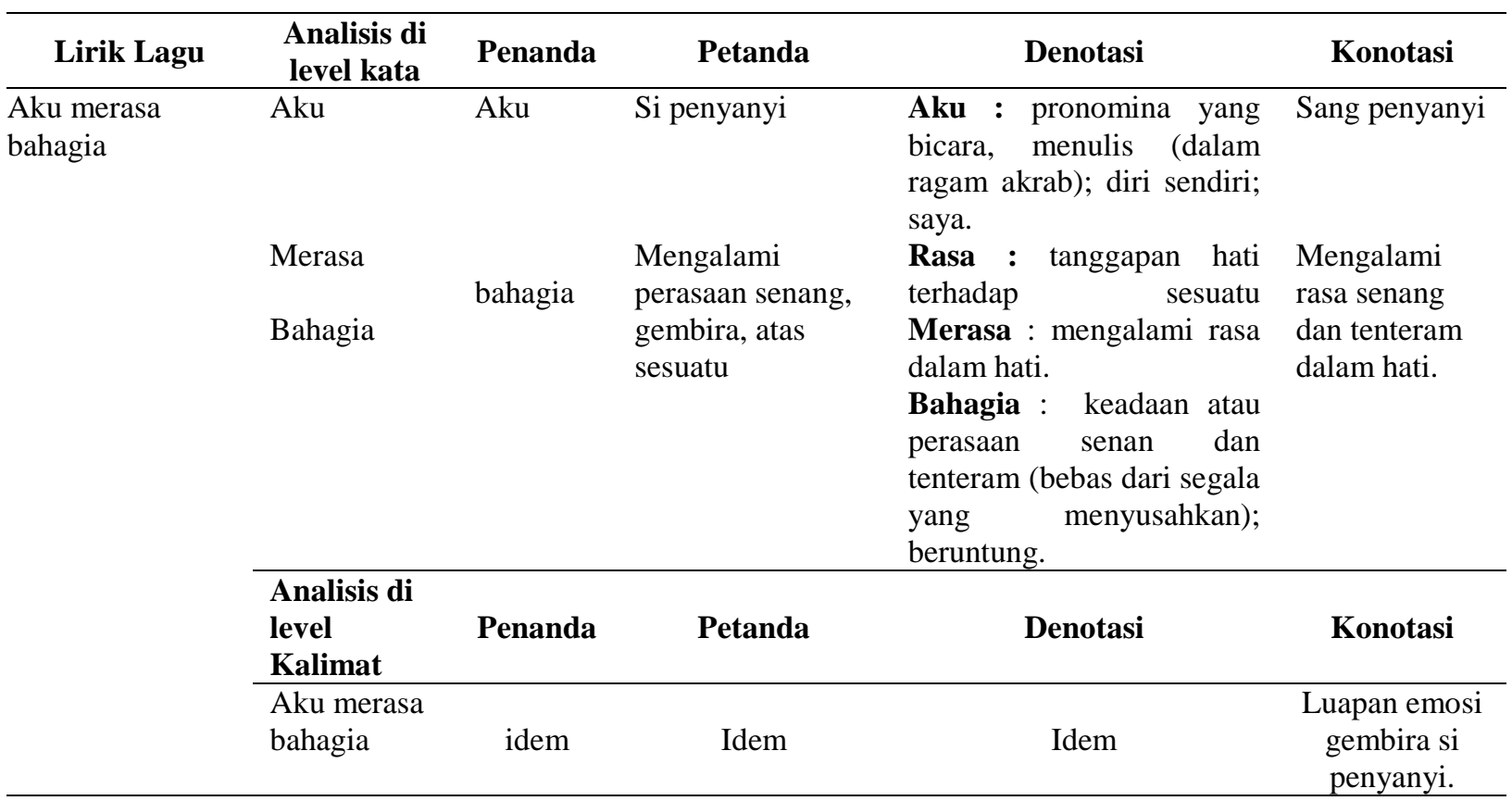


Tabel 3. Analisis Kualitatif Semiotika Lagu 'Cinta Satu Malam’ Melinda

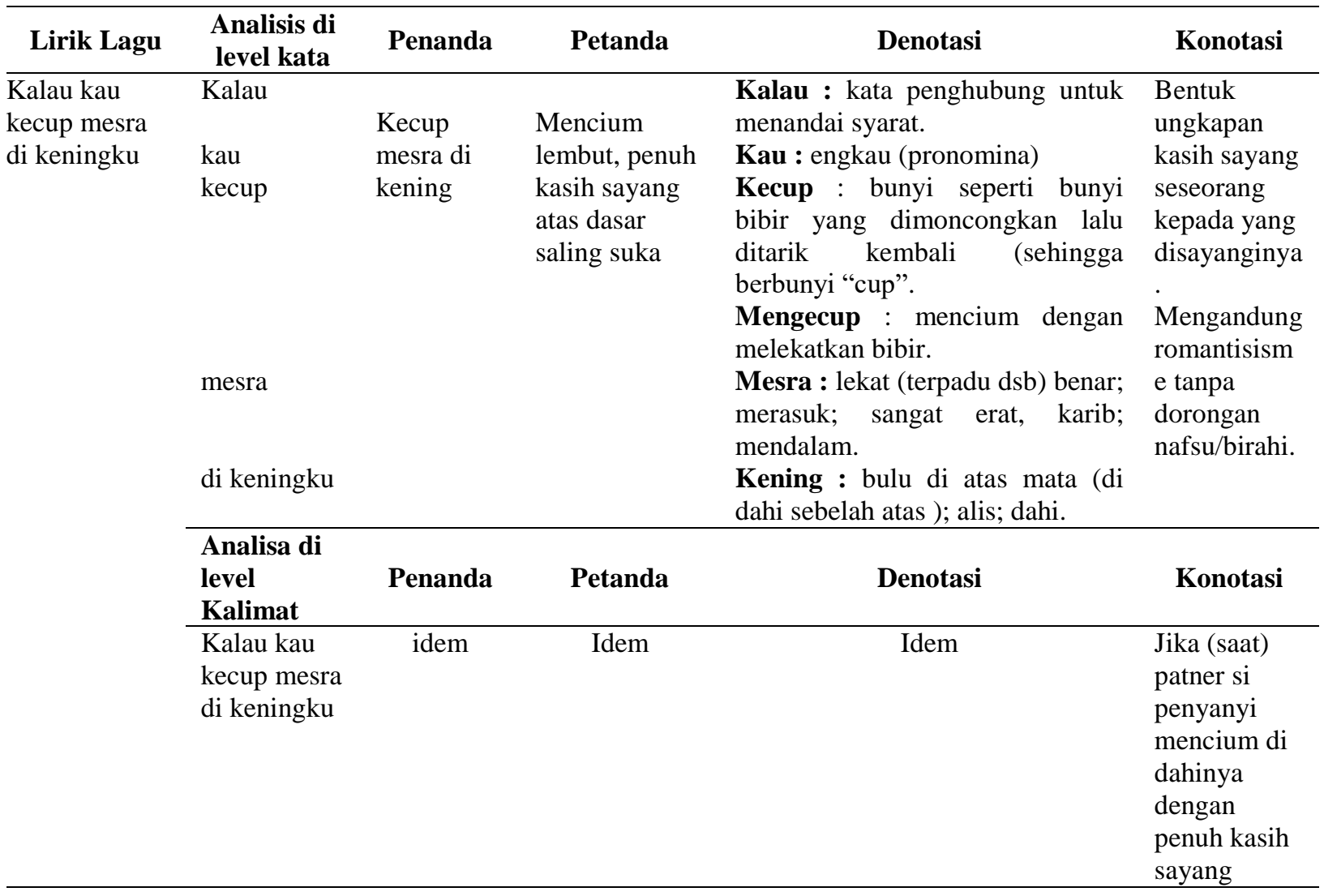

Tabel 4. Analisis Kualitatif Semiotika Lagu 'Cinta Satu Malam’ Melinda

\begin{tabular}{|c|c|c|c|c|c|}
\hline Lirik Lagu & $\begin{array}{l}\text { Analisis di } \\
\text { level kata }\end{array}$ & Penanda & Petanda & Denotasi & Konotasi \\
\hline \multirow{8}{*}{$\begin{array}{l}\text { Ku rasa bagai } \\
\text { di Surga }\end{array}$} & $\mathrm{Ku}$ & \multirow{6}{*}{$\begin{array}{l}\text { Ku rasa } \\
\text { bagai di } \\
\text { surga }\end{array}$} & \multirow{6}{*}{$\begin{array}{l}\text { Perasaan } \\
\text { senang, } \\
\text { bahagia } \\
\text { yang luar } \\
\text { biasa }\end{array}$} & $\mathbf{K u}: \mathrm{Aku}$, diri sendiri & \multirow{6}{*}{$\begin{array}{l}\text { Ungkapan } \\
\text { kebahagiaan } \\
\text { yang luar } \\
\text { biasa }\end{array}$} \\
\hline & rasa & & & $\begin{array}{l}\text { Rasa : tanggapan hati terhadap } \\
\text { sesuatu. }\end{array}$ & \\
\hline & bagai & & & $\begin{array}{l}\text { Bagai : kata depan untuk menyatakan } \\
\text { perbandingan; seperti; laksana. }\end{array}$ & \\
\hline & & & & $\begin{array}{l}\text { Surga : alam akhirat yang } \\
\text { membahagiakan roh manusia yang }\end{array}$ & \\
\hline & di surga & & & $\begin{array}{l}\text { hendak tinggal di dalamnya (dalam } \\
\text { keabadian). }\end{array}$ & \\
\hline & & & & $\begin{array}{l}\text { Surga dunia : kenikmatan } \\
\text { (kesenangan, } \\
\text { diperoleh hanya selama miaan)yang } \\
\text { di dunia; kenikmatan duniawi. }\end{array}$ & \\
\hline & $\begin{array}{l}\text { Analisa di } \\
\text { level } \\
\text { Kalimat }\end{array}$ & Penanda & Petanda & Denotasi & Konotasi \\
\hline & $\begin{array}{l}\text { Ku rasa } \\
\text { bagai di } \\
\text { surga }\end{array}$ & Idem & Idem & Idem & $\begin{array}{l}\text { Ungkapan } \\
\text { kebahagiaan } \\
\text { yang luar } \\
\text { biasa }\end{array}$ \\
\hline
\end{tabular}


Tabel 5. Analisis Kualitatif Semiotika Lagu 'Cinta Satu Malam’ Melinda

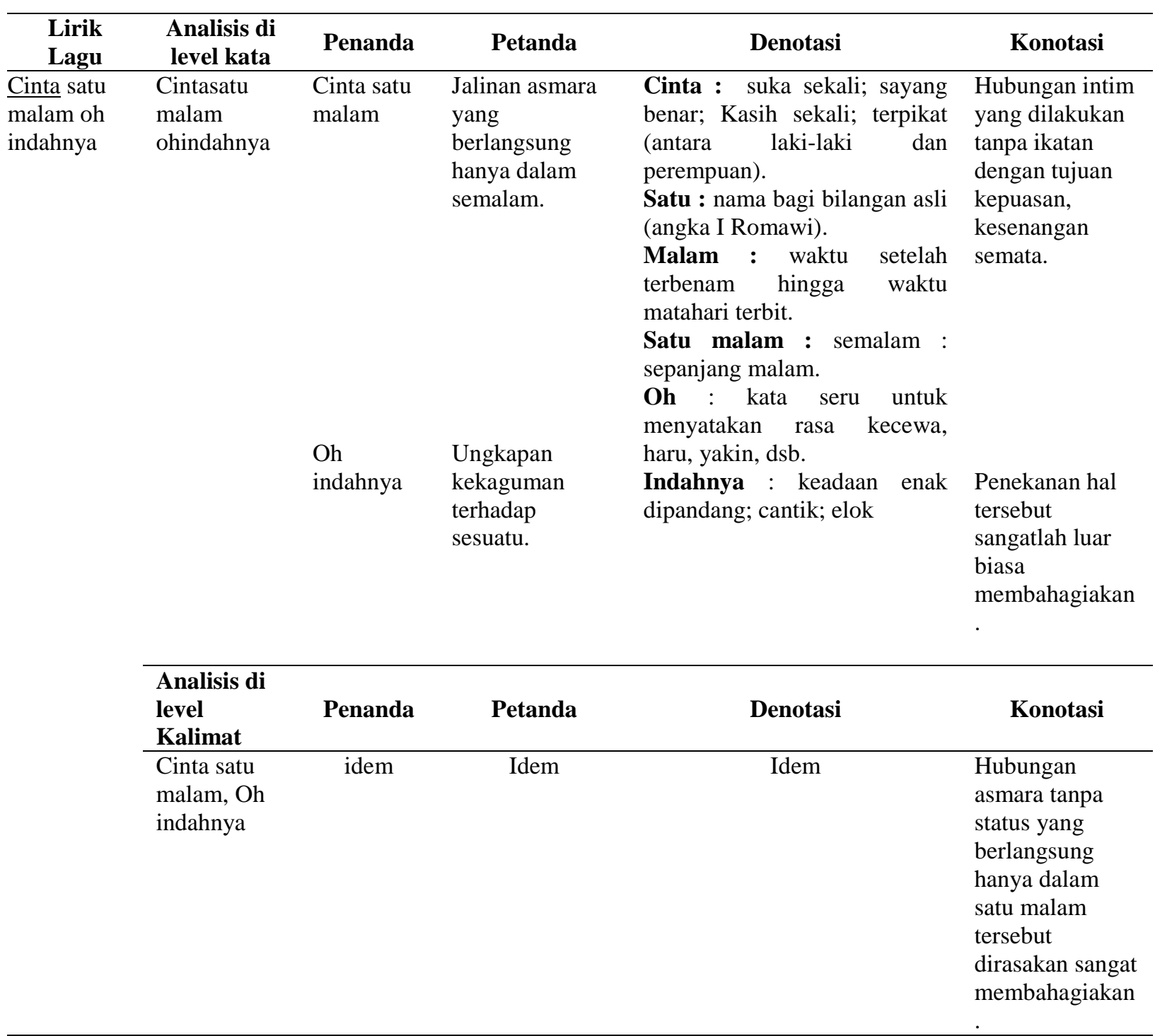


Tabel 6. Analisis Kualitatif Semiotika Lagu 'Cinta Satu Malam’ Melinda

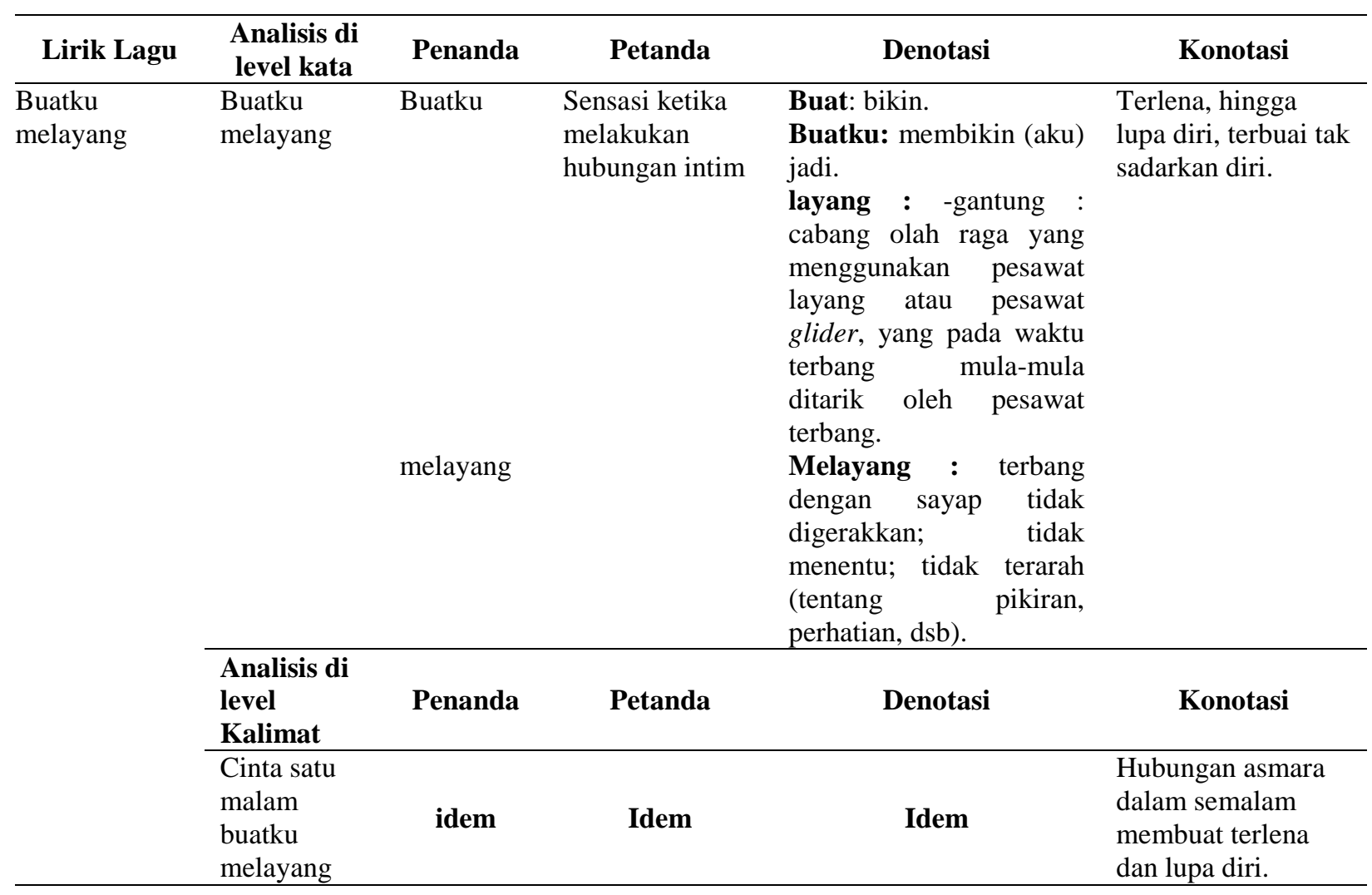


Tabel 7. Analisis Kualitatif Semiotika Lagu 'Cinta Satu Malam’ Melinda

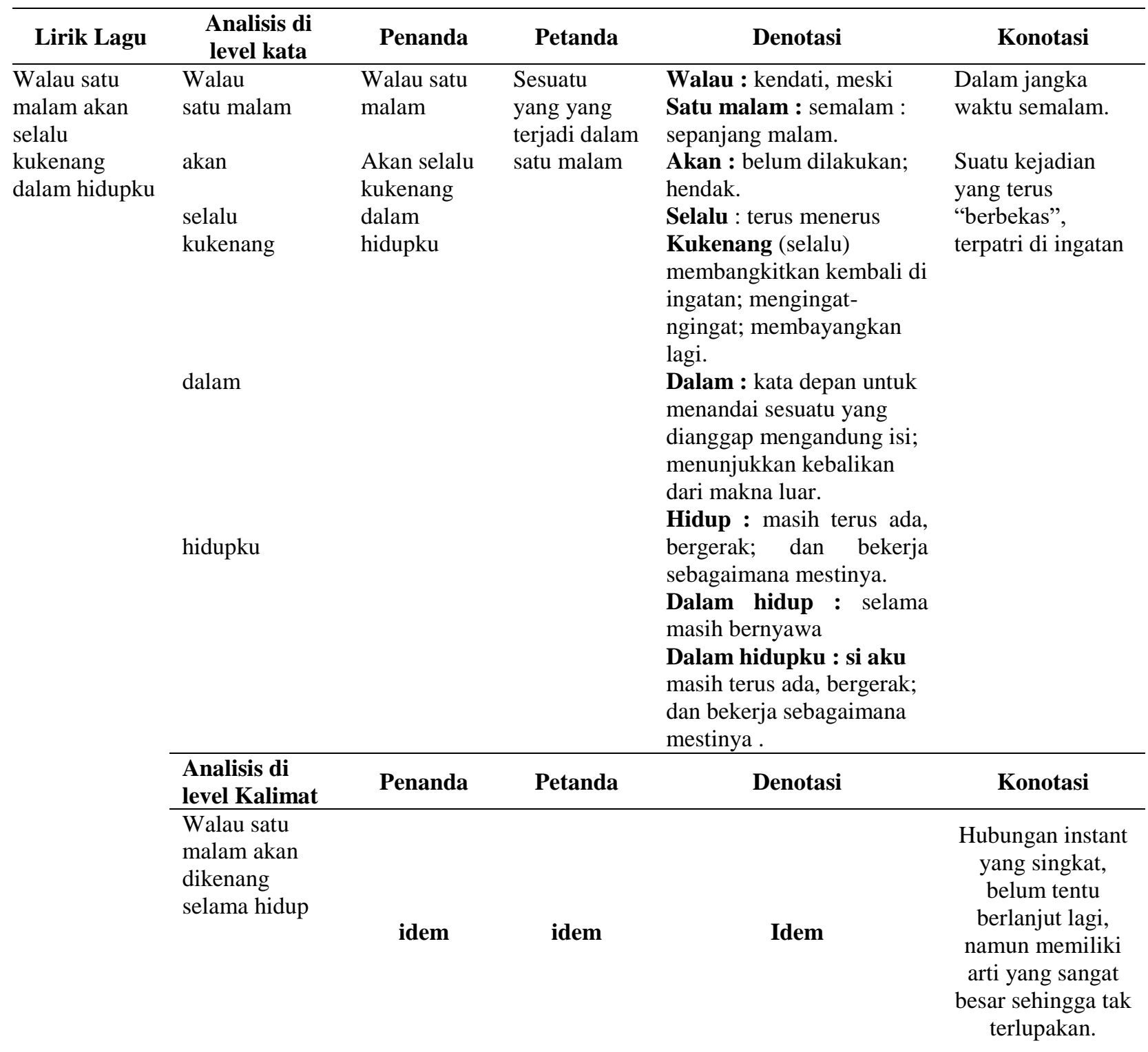

Tabel 8. Analisis Kualitatif Semiotika Lagu 'Cinta Satu Malam’ Melinda

\begin{tabular}{ccclll}
\hline Lirik Lagu & $\begin{array}{l}\text { Analisis di } \\
\text { level kata }\end{array}$ & Penanda & \multicolumn{1}{c}{ Petanda } & \multicolumn{1}{c}{ Denotasi } & Konotasi \\
\hline Selama-lamanya & $\begin{array}{l}\text { Selama- } \\
\text { lamanya }\end{array}$ & $\begin{array}{l}\text { Selama- } \\
\text { lamanya }\end{array}$ & $\begin{array}{l}\text { Sesuatu yang sangat } \\
\text { berkesan sehingga } \\
\text { menjadi } \\
\text { pengalaman yang } \\
\text { tak terlupakan }\end{array}$ & $\begin{array}{l}\text { Lama : panjangnya } \\
\text { waktu } \\
\text { Selama-lamanya : } \\
\text { paling lama; tidak ada } \\
\text { habis-habisnya, } \\
\text { sepanjang masa, ; kekal. }\end{array}$ & $\begin{array}{l}\text { Selalu, sepanjang } \\
\text { masa, kekal. }\end{array}$ \\
& & & & &
\end{tabular}




\section{Continued}

\begin{tabular}{|c|c|c|c|c|}
\hline $\begin{array}{l}\text { Analisis di } \\
\text { level Kalimat }\end{array}$ & Penanda & Petanda & Denotasi & Konotasi \\
\hline $\begin{array}{l}\text { Walau satu } \\
\text { malam akan } \\
\text { kukenang } \\
\text { selama- } \\
\text { lamanya } \\
\end{array}$ & idem & Idem & Idem & $\begin{array}{l}\text { Meski berlangsung } \\
\text { sangat singkat } \\
\text { (semalam), kejadian } \\
\text { itu akan tetap diingat } \\
\text { sepanjang masa. }\end{array}$ \\
\hline
\end{tabular}

Tabel 9. Analisis Kualitatif Semiotika Lagu 'Cinta Satu Malam’ Melinda

\begin{tabular}{|c|c|c|c|c|c|}
\hline Lirik Lagu & $\begin{array}{c}\text { Analisis di level } \\
\text { kata }\end{array}$ & Penanda & Petanda & Denotasi & Konotasi \\
\hline \multirow[t]{4}{*}{$\begin{array}{l}\text { Sentuhanmu } \\
\text { membuatku } \\
\text { terlena }\end{array}$} & Sentuhan-mu & $\begin{array}{l}\text { Sentuhan } \\
\text {-mu }\end{array}$ & $\begin{array}{l}\text { Kontak fisik yang } \\
\text { dilakukan } \\
\text { seseorang }\end{array}$ & $\begin{array}{l}\text { Sentuh : kena sedikit } \\
\text { pada; bersingung } \\
\text { (berantuk) sedikit; } \\
\text { bersenggol. 2) } \\
\text { bersetubuh } \\
\text { Sentuhan :Hasil } \\
\text { menyentuh, singgungan, } \\
\text { senggolan. } \\
\text { Sentuhanmu : } \\
\text { senggolan, singgungan } \\
\text { lawan bicara }\end{array}$ & $\begin{array}{l}\text { Penggambaran } \\
\text { tindakan dalam } \\
\text { berhubungan intim. }\end{array}$ \\
\hline & $\begin{array}{l}\text { Membuatku } \\
\text { terlena }\end{array}$ & $\begin{array}{l}\text { Membuat } \\
\mathrm{ku}\end{array}$ & $\begin{array}{l}\text { Perasaan luluh } \\
\text { karena bahagia }\end{array}$ & $\begin{array}{l}\text { Buat : bikin, kerjakan, } \\
\text { lakukan } \\
\text { Membuat : } \\
\text { menyebabkan } \\
\text { Ku : aku } \\
\text { Membuatku : } \\
\text { menyebabkan aku (jadi) } \\
\text { Lena : nyenyak, tidak } \\
\text { sadar; lengah; lalai } \\
\text { Terlena : sangat asiknya, } \\
\text { dengan asyiknya; } \\
\text { bersenang-senang }\end{array}$ & $\begin{array}{l}\text { Merasa puas yang } \\
\text { teramat sangat. }\end{array}$ \\
\hline & $\begin{array}{l}\text { Analisis di level } \\
\text { Kalimat }\end{array}$ & Penanda & Petanda & Denotasi & Konotasi \\
\hline & $\begin{array}{l}\text { Sentuhanmu } \\
\text { membuatku } \\
\text { terlena }\end{array}$ & Idem & idem & Idem & $\begin{array}{l}\text { Merasa sangat puas } \\
\text { dalam (saat) } \\
\text { berhubungan intim }\end{array}$ \\
\hline
\end{tabular}

Tabel 10. Analisis Kualitatif Semiotika Lagu 'Cinta Satu Malam’ Melinda

\begin{tabular}{|c|c|c|c|c|c|c|}
\hline Lirik Lagu & $\begin{array}{l}\text { Analisis di } \\
\text { level kata }\end{array}$ & Penanda & $\mathbf{P e}$ & & Denotasi & Konotasi \\
\hline $\begin{array}{l}\text { Aku telah } \\
\text { terbuai mesra }\end{array}$ & $\begin{array}{l}\text { Aku } \\
\text { telah terbuai } \\
\text { mesra }\end{array}$ & $\begin{array}{l}\text { Terbuai } \\
\text { mesra }\end{array}$ & $\begin{array}{l}\text { merasa } \\
\text { terlena }\end{array}$ & sangat & $\begin{array}{l}\text { Aku : diri sendiri, saya. } \\
\text { Telah : sudah } \\
\text { Buai : gerak mengayun, } \\
\text { Terbuai : menjadi lupa akan } \\
\text { hal lain; terlena (karena } \\
\text { sesuatu) } \\
\text { Mesra : lekat (terpadu dsb) } \\
\text { benar; merasuk; sangat erat, } \\
\text { karib; mendalam. }\end{array}$ & $\begin{array}{l}\text { Perasaan } \\
\text { nyaman, } \\
\text { dimanjakan, } \\
\text { sehingga } \\
\text { terlena. }\end{array}$ \\
\hline
\end{tabular}


Tabel 11. Analisis Kualitatif Semiotika Lagu 'Cinta Satu Malam’ Melinda

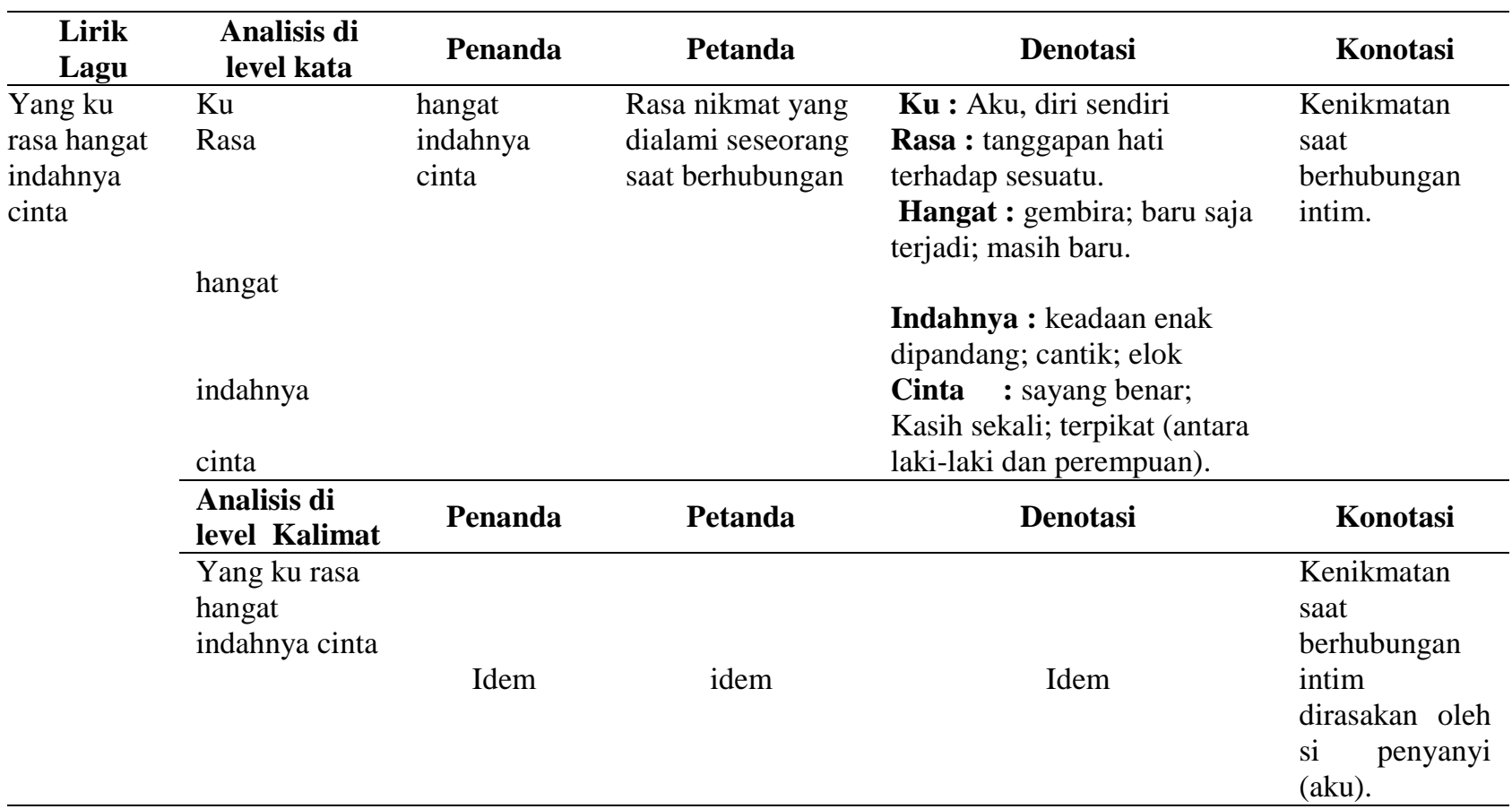

Tabel 12. Analisis Kualitatif Semiotika Lagu 'Cinta Satu Malam’ Melinda

\begin{tabular}{|c|c|c|c|c|c|}
\hline $\begin{array}{l}\text { Lirik } \\
\text { Lagu }\end{array}$ & $\begin{array}{c}\text { Analisis di level } \\
\text { kata }\end{array}$ & Penanda & Petanda & Denotasi & Konotasi \\
\hline \multirow[t]{3}{*}{$\begin{array}{l}\text { Hasratku } \\
\text { kian } \\
\text { membara }\end{array}$} & $\begin{array}{l}\text { Hasratku } \\
\text { kian } \\
\text { membara }\end{array}$ & $\begin{array}{l}\text { Hasratku } \\
\text { kian } \\
\text { membara }\end{array}$ & $\begin{array}{l}\text { Keinginan untuk } \\
\text { bercinta semakin } \\
\text { kuat }\end{array}$ & $\begin{array}{l}\text { Hasratku : keinginan yang } \\
\text { kuat. } \\
\text { Kian : segitu, sebanyak itu; } \\
\text { makin bertambah. } \\
\text { Bara : barang sesuatu } \\
\text { (arang) yang terbakar dan } \\
\text { masih berapi } \\
\text { Membara : berapi-api } \\
\text { (semangat). }\end{array}$ & $\begin{array}{l}\text { Birahi, nafsu yang } \\
\text { makin bergejolak. }\end{array}$ \\
\hline & $\begin{array}{l}\text { Analisis di level } \\
\text { Kalimat }\end{array}$ & Penanda & Petanda & Denotasi & Konotasi \\
\hline & $\begin{array}{l}\text { Hasratku kian } \\
\text { membara }\end{array}$ & Idem & Idem & Idem & $\begin{array}{c}\text { Birahi, nafsu si } \\
\text { penyanyi (aku) } \\
\text { meningkat. } \\
\text { (Semakin ingin } \\
\text { melakukan } \\
\text { hubungan intim.) }\end{array}$ \\
\hline
\end{tabular}


Jika dianalisis secara keseluruhan, lagu ini menggambarkan perasaan si penyanyi yang pernah mengalami "cinta satu malam". Cinta satu malam di sini memiliki konotasi hubungan gelap, ilegal antara dua orang yang dilakukan atas dasar suka, namun hanya dilakukan dalam semalam - tidak berkelanjutan. "Cinta semalam" yang berhubungan dengan hubungan gelap ini juga berkonotasi tindakan yang dilakukan dalam hubungan seksual/intim.

"Walau cinta kita sementara aku merasa bahagia

Kalau kau kecup mesra di keningku ku rasa bagai di surga”

Hal tersebut tersirat dan tersurat di lagu tersebut. Si penyanyi menggambarkan bahwa meskipun hubungan cinta mereka hanya dilakukan dalam satu malam ia merasa bahagia. Bahkan selanjutnya ia menggambarkan kronologis perbuatan mereka dengan tentunya memaparkan perasaannya Ia merasa senang luar biasa saat keningnya dikecup mesra. Kata mesra menunjukkan adanya kedekatan yang sangat karib antara si aku dengan patner satu malamnya, sehingga dia tidak menolak bahkan menikmati diperlakukan seperti itu. Perasaan yang timbul saat ia dikecup dibandingkan dengan berada di tempat seperti surga, yang berarti dia merasakan kebahagiaan yang amat sangat.

“Cinta satu malam, Oh indahnya Cinta satu malam buatku melayang”

$\mathrm{Si}$ penyanyi mengungkapkan kebahagiannya melakukan cinta satu malam dengan memandangnya sebagai suatu hal yang indah dan mengulang-ngulang menyebut tindakannya. Dengan menggunakan kata seru"oh" berarti si aku bahkan mengagumi keindahan perbuatan, emosi dan perasaan yang timbul dalam cinta satu malamnya. Ia menyebutkan bahwa dalam tindakannya ia merasa dibuat melayang oleh patnernya. Sensasi melayang berkonotasi sensasi yang luar biasa, perasaan ringan yang sangat menyenangkan.

"Walau satu malam akan selalu kukenang dalam hidupku Selama-lamanya”

Setelah menggambarkan perasaan dan sensasi yang dialaminya, si aku menyebutkan bahwa ia akan menjaganya dalam memori selama hidupnya, bahkan selama-lamanya. Suatu kejadian atau hal akan diingat dan dijadikan hanya jika kejadian atau hal tersebut memiliki arti yang sedemikian besar, pengalaman berharga atas sesuatu, atau pelajaran atau hikmah yang terkandung. Dalam hal ini berarti si aku memandang hubungan cinta semalamnya sebagai pengalaman yang sangat berharga sehingga ia akan selalu mengingatnya sepanjang hayat.

"Sentuhanmu membuatku terlena, aku telah terbuai mesra

Yang ku rasa hangat indahnya cinta, hasratku kian membara"

Kata sentuhan mengandung konotasi kontak fisik yang dilakukan atas motif tertentu, yang dalam hal ini bisa membuat si aku merasa terbuai mesra. Kontak fisik tersebut bisa berupa belaian, elusan, kecupan atau tindakan seksual lain 


\section{Diskusi}

Keberadaan dan populernya lagu "Cinta Satu Malam" ini menunjukkan adanya pergeseran nilai nilai moral pada masyarakat. Merujuk pada pendapat Andrew N. Weintraub (2010) tentang sejarah dangdut mengenai fungsi lagu dangdut sebagai korelasi dan juga transmisi kultural, maka dapat dikatakan bahwa keberadaan lagu "Cinta Satu Malam" ini adalah representasi perilaku free sex yang ada pada masyarakat.

Kemudian dikaitkan dengan bahasa yang digunakan dalam lirik lagu ini, maka bahasa lagu "Cinta Satu Malam" juga sangat gamblang atau menggunakan kata-kata yang eksplisit dalam menyampaikan maksud dari si pencipta lagu dan atau si penyanyi. Secara umum, bahasan tentang seksualitas dianggap sebagai topik sensitif yang pantang dibicarakan secara terbuka di keluarga hingga ke publik. Keengganan untuk membicarakan seksualitas tersebut, menggambarkan sikap konservatif yang melihat seksualitas dari segi moral, agama dan norma budaya. Masyarakat Indonesia umumnya masih mengganggap topik tentang seks sebagai suatu yang alamiah.

Namun, dalam dunia yang berubah cepat dengan informasi memainkan peranan penting melalui media massa, terdapat suatu dilema, yaitu orang-orang yang terperangkap di antara nilai-nilai budaya seksualitas dan realitas sosial seksualitas yang ada. Seks yang merupakan topik yang 'sangat pribadi' dan secara politis merupakan topik yang 'sensitif' dan sangat tabu dibicarakan menjadi konsumsi masyarakat, apalagi jika menjangkau anak kecil. Permasalahan tersebut bisa diterima masyarakat dari berbagai media massa, salah satunya adalah lagu dangdut.

Pada awalnya, dangdut ditujukan untuk masyarakat bawah dengan bahasa yang mudah dipahami. Tema yang diangkat dalam lagu dangdut ini biasanya berkisar tentang kehidupan sehari-hari. Namun, seiring dengan perkembangan kehidupan masyarakat, tema yang diangkat dalam lirik lagu juga ikut berubah. Para pencipta lagu memilih untuk melahirkan karya-karya yang sesuai dengan zaman sekarang, misalnya saja kehidupan percintaan yang lengkap dengan bumbu cinta semalamnya yang mulai menyebar di kalangan masyarakat. Pemilihan tema-tema yang berbau seks tersebut dianggap bisa menaikkan jumlah penjualan, sehingga bisa dikatakann pula bahwa representasi seks bebas yang diangkat dalam lagu ini juga merupakan upaya komodifikasi lagu itu sendiri.

Hal-hal yang tentang seks mulanya merupakan hal tabu yang dilarang dimuat di media, bahkan masyarakat pun enggan membicarakannya. Namun, dengan perubahan budaya dan gaya hidup masyarakat memunculkan adanya pergeseran nilai dan norma, sehingga saat ini hal-hal tersebut bisa dengan mudah dibicarakan serta ditemukan dalam berbagai media, misalnya pada lirik lagu. Bahasa yang digunakan pencipta lagu, khususnya lagu dangdut merupakan cerminan dari keadaan masyarakat atau realitas sosial yang berkembang, sehingga sifatnya lebih menceritakan kondisi masyarakat yang sebenarnya. Namun, seringkali bahasa yang digunakan oleh para pencipta tersebut terlalu eksplisit, sehingga menggambarkan secara terbuka makna dari lagu tersebut.

Pencipta lagu menuliskan lirik lagu ciptaanya dengan kiasan yang ekspresif untuk menggambarkan makna atau realitas yang ingin diangkat melalui lagu tersebut. Lirik lagu dituliskan dengan makna konotatif bersifat subjektif, yang lebih bersifat terbuka dan berani sebagai nilai rasa lagu tersebut. Penggunaan konotasi yang dimaksud dalam hal ini adalah adanya tingkat pertandaan yang menjelaskan hubungan antara penanda dan pertanda yang didalamnya beroperasi makna yang tidak emplisit, tidak langsung dan tidak pasti (terbuka 
terhadap berbagai kemungkinan). Pada lagu Cinta Satu Malam tersebut hubungan sentuhan fisik yang menurut pandangan sosial masyarakat di Indonesia lazim terjadi dalam pasangan suami istri (dalam sebuah ikatan pernikahan) diangkat menjadi hal seolah wajar dilakukan oleh sepasang anak muda yang jatuh cinta hanya dalam semalam tanpa kesan negatif di dalamnya. Penyampaian kesan sukacita dan bahagia dalam lirik lagu tersebut tentu berusaha menunjukkan adanya konsensus bahwa hubungan seks bebas dalam semalam tidaklah menjadi masalah asalkan suka sama suka atau saling cinta. Representasi perilaku seks bebas ini menunjukkan pula bahwa wacana hubungan percintaan yang semula privat bahkan tabu, kini boleh diungkapkan dengan gamblang sebagai hal yang lumrah terjadi.

\section{KESIMPULAN DAN SARAN}

\section{Kesimpulan}

Realitas sosial yang akan dikaji tersebut adalah pola perilaku seks bebas di kalangan masyarakat melalui lirik lagu. Lagu yang dikaji dalam penelitian ini adalah lagu dangdut berirama house music berjudul "Cinta Satu Malam" yang bertemakan 'cinta semalam'. bahasa yang digunakan dalam lirik lagu "Cinta Satu Malam" secara eksplisit merepresentasikan fenomena seks bebas sebagai salah satu realitas sosial serta menunjukkan terdapat suatu pergeseran nilai bahasa khususnya pada pemilihan kata pada lagu dangdut. Lirik lagu ini menonjolkan kata/bahasa eksplisit mengenai seks bebas sebagai hal atau wacana yang lumrah di tengah masyarakat.

\section{Saran}

Berdasarkan hasil penelitian, penulis menyarankan adanya penelitian-penelitian sejenis untuk mengkaji realitas sosial, berdasarkan lirik lagu. Penelitian mengenai realitas sosial berbasis lirik lagu dapat menambah perbendaharaan pemahaman terhadap konteks sosio-budaya yang sedang terjadi dalam masyarakat.

\section{Ucapan Terima Kasih (Acknowledgement)}

Penelitian ini adalah penyempurnaan dari riset awal kajian media yang penulis lakukan secara mandiri melalui hasil pembekalan pada program Academic Faculty Development (AFD) 2016 yang diselenggarakan Universitas Tarumanagara.

\section{REFERENSI}

Ayumi, T. (2005). Representasi relasi gender dalam lirik lagu dangdut yang diciptakan pencipta perempuan: Studi semiotika lirik lagu dangdut periode Tahun 1970-an, 1980-an, 1990-1n dan 2000-an. Skripsi tidak diterbitkan, Fakultas Ilmu Komunikasi

Danesi, M. (2010). Pengantar memahami semiotika media. Yogyakarta: Jalasutra.

Eriyanto. (2001). Analisis wacana: Pengantar analisa teks media. LKIS: Yogyakarta.

Kamus Besar Bahasa Indonesia edisi ke tiga Jakarta: Balai Pustaka.

Kurniawan, T. (2009). Analisis gaya bahasa ironi dan pesan moral lagu-lagu Slank dalam album antikorupsi tinjauan semiotik. Skripsi tidak diterbitkan, Universitas Muhammadiyah, Surakarta.

Luaylik, F., dan Johny A. K. (2009) Perkembangan musik dangdut Indonesia 1960-an-1990an. Jurnal Verleden, 1(1), 1-109.

Nazir, M. (2003). Metode Penelitian. Jakarta: Penerbit Ghali Indonesia

Sobur, A. (2004). Analisis teks media: Suatu pengantar untuk analisis wacana, analisis semiotik, dan analisis framing. Bandung: Remaja Rosdakarya 
Sobur, A. (2003). Semiotika komunikasi. Bandung: Rosadakarya.

Storey, J. (2006). Cultural theory and popular culture an Introduction (4 ${ }^{\text {th }}$ ed.). Georgia, United States: University of Georgia Press.

Suryadi. Sejarah dangdut: Sebuah sejarah musikal dan sosial dari musik paling poluler di Indonesia. Journal of Arts Discourse. 12(1)

Wiradinata, Galih. E. (2012). Representasi kemiskinan struktural dalam video klip (analisis semiotika dalam video klip superglad dan navicula). Skrisi tidak diterbitkan, Universitas Muhammadiyah Yogyakarta 